\title{
An Alternative to Clay in Building Materials: Red Mud Sintering Using Fly Ash via Taguchi's Methodology
}

\author{
Suchita Rai, ${ }^{1,2}$ Dilip H. Lataye, ${ }^{3}$ M. J. Chaddha, ${ }^{1}$ R. S. Mishra, ${ }^{1}$ P. Mahendiran, ${ }^{1}$ \\ J. Mukhopadhyay, ${ }^{4}$ ChangKyoo Yoo, ${ }^{5}$ and Kailas L. Wasewar ${ }^{2,5}$ \\ ${ }^{1}$ Jawaharlal Nehru Aluminium Research Development and Design Centre, Wadi, Amravati Road, Nagpur, India \\ ${ }^{2}$ Advanced Separations and Analytical Laboratory, Department of Chemical Engineering, \\ Visvesvaraya National Institute of Technology (VNIT), Nagpur, Maharashtra 440011, India \\ ${ }^{3}$ Department of Civil Engineering, Visvesvaraya National Institute of Technology (VNIT), Nagpur, Maharashtra 440011, India \\ ${ }^{4}$ Indian Institute of Technology, Gandhinagar, Gujarat, India \\ ${ }^{5}$ Environmental Management \& Systems Engineering Lab (EMSEL), Department of Environmental Science and Engineering, \\ College of Engineering, Kyung Hee University, Seocheon-dong 1, Giheung-gu, Gyeonggi-do, Yongin-si 446-701, Republic of Korea
}

Correspondence should be addressed to ChangKyoo Yoo; ckyoo@khu.ac.kr and Kailas L. Wasewar; k_wasewar@rediffmail.com

Received 29 May 2013; Revised 6 September 2013; Accepted 6 September 2013

Academic Editor: Markku Leskela

Copyright (C) 2013 Suchita Rai et al. This is an open access article distributed under the Creative Commons Attribution License, which permits unrestricted use, distribution, and reproduction in any medium, provided the original work is properly cited.

\begin{abstract}
"Red mud" or "bauxite residue" is a highly alkaline waste generated from alumina refinery with a pH of 10.5-12.5 which poses serious environmental problems. Neutralization or its treatment by sintering in presence of additives is one of the methods for overcoming the caustic problem as it fixes nearly all the leachable free caustic soda present in red mud. In the present study, feasibility of reducing the alkaline nature of red mud by sintering using fly ash as an additive via Taguchi methodology and its use for brick production, as an alternative to clay, is investigated. The analysis of variance (ANOVA) shows that sintering temperature is the most significant parameter in the process. A pH of 8.9 was obtained at $25-50 \%$ of red mud and $50-75 \%$ fly ash with water and temperature of $1100^{\circ} \mathrm{C}$. Alternatively $50 \%$ of red mud can be mixed with $50 \%$ of fly ash with water at temperature of $1200^{\circ} \mathrm{C}$ to get a $\mathrm{pH}$ of about 8.4 . The mechanism of this process has been explained with also emphasis on chemical, mineralogical, and morphological analysis of the sintered red mud. The results would be extremely useful in utilization of red mud in building and construction industry.
\end{abstract}

\section{Introduction}

The Bayer process of extraction of alumina from bauxite remains the most economical process till date. In the Bayer process, the insoluble product generated after bauxite digestion with sodium hydroxide at elevated temperature and pressure to produce alumina is known as "red mud" or "bauxite residue" which is highly alkaline in nature with a $\mathrm{pH}$ of 10.5-12.5. Red mud is a mixture of compounds originally present in bauxite and of compounds formed during the Bayer cycle. The main reaction of aluminum oxide dissolution in the Bayer process is as follows:

$$
2 \mathrm{NaOH}+\mathrm{Al}_{2} \mathrm{O}_{3} \cdot 3 \mathrm{H}_{2} \mathrm{O} \longrightarrow \mathrm{Na}_{2} \mathrm{O} \cdot \mathrm{Al}_{2} \mathrm{O}_{3}+4 \mathrm{H}_{2} \mathrm{O}
$$

Depending on the raw material processed, 1-2.5 tons of red mud is generated per ton of alumina produced [1].
An enormous quantity of red mud is generated worldwide ( $\sim 75$ million tons) every year posing a major environmental problem. In India, about 4.71 million tons/annum of red mud is produced which is $6.25 \%$ of world's total generation [2]. Red mud is disposed as semidry material in red mud pond or abandoned bauxite mines and as slurry having a high solid concentration of $30-60 \%$. Problems associated with the disposal of red mud waste include its high $\mathrm{pH}$, alkali seepage into underground water, safety in storage, alkaline air borne dust emissions, and the vast area of land required for disposal. Up to 2 tons of liquor with a significant alkalinity of 5-20 g/L caustic (as $\mathrm{Na}_{2} \mathrm{CO}_{3}$ ) accompanies every ton of dry mud. Neutralization of red mud will help to reduce the environmental impact caused due to storage activities of the residue and will also open opportunities for the reuse of the residue which till now has been prevented because of the high $\mathrm{pH}$. 
It will also reduce degradation of clay or synthetic liners of red mud ponds. The overall risk of groundwater contamination would be reduced significantly by neutralizing red mud.

The literature shows that red mud can be treated with any of these methods to make it environmentally benign: acid leaching, $\mathrm{CO}_{2}$ treatment, bioleaching, seawater neutralization, and sintering. A review of neutralization processes of red mud and its utilization is given by investigators [3].

A considerable research has been done on the utilization of red mud as a raw material for the production of a range of building products by sintering of red mud. Red mud can be used as a constructional/building material in bricks, blocks, light weight aggregates, roofing tiles, glass ceramics, cement industry as cements and special cements, and concrete industry. Red mud is made into useful ceramics articles by mixing $51-90 \%$ of the weight of red mud with $10-49 \%$ of the weight of at least one mineral and/or silicate containing material, shaping the mixture and firing it at a temperature of $950^{\circ}-$ $1250^{\circ} \mathrm{C}[4]$. A patent [5] claims a process for manufacturing fired bricks wherein 50-90 wt\% of red mud can be used along with clay and a water fixing agent. The raw bricks are dried with heated gases at a temperature below $70^{\circ} \mathrm{C}$ and subsequently fired at a temperature between $900^{\circ}-1100^{\circ} \mathrm{C}$. Though all these studies are based on sintering of red mud and its use, very little has been stated about the change in $\mathrm{pH}$ with the sintering temperature and other parameters. The ways in which these factors may interact in the neutralization or treatment process are poorly understood.

Hence the present study focuses on the study of change in $\mathrm{pH}$ in the sintering process due to a wide range of factors. The treatment process involves mixing of silicate material such as fly ash with red mud in presence of water. Fly ash is the by-product of burning of coal and is available from coalbased thermal power plants and other coal burning centers. An estimated availability of fly ash in India is about 80100 million tons per year [6]. Every thermal power plant generating $1000 \mathrm{MW}$ power on an average produces 3500 tons of fly ash every day [6]. It is estimated that an area of about 28,000 ha of land will be necessary to dump all the fly ash available in the country. The present utilization level of fly ash in India is less than 10\% [6]. Fly ash contains 1 to $100 \mu \mathrm{m}$ suspended particulates affecting plant growth besides being a health hazard [7]. Indian red mud is rich in titania and iron in alkali oxides while the fly ash is rich in silica and alumina. These features contribute to the optimum composition for brick making [7].

Hence use of fly ash has been made as a silicate material in sintering of red mud. In this way both the wastes can be made nonhazardous and can be reused.

Taguchi's experimental methodology has been employed to evaluate the $\mathrm{pH}$ values. Taguchi's design of experiments has been used extensively in product quality assessment and several other studies [8-12]. Taguchi's fractional factorial design of experiments has been used to examine the effect of significant parameters such as weight of red mud, weight of silicate material added, volume of water, and reaction temperature on the response characteristic ( $\mathrm{pH}$ of red mud slurry). The average values and the signal to noise $(S / N)$ ratio of the quality response characteristic for each parameter at 3 levels of their values have been calculated from the experimental data. The response curves have been graphically represented to reflect any change in the quality characteristic and $S / N$ ratio with the variation in process parameters. These response curves are used to identify the effects of various parameters on the response characteristic. Significant parameters have been identified by using the analysis of variance (ANOVA) on the experimental data.

\section{Materials and Methods}

2.1. Materials. Red mud from an alumina refinery situated at the eastern coast of India $\left(18^{\circ} 49^{\prime} 9^{\prime \prime} \mathrm{N}, 82^{\circ} 57^{\prime} 52^{\prime \prime} \mathrm{E}\right)$ was ground to 100 mesh size and used for the study. Chemical composition of red mud is $\mathrm{Al}_{2} \mathrm{O}_{3}(16-17.5 \%), \mathrm{Fe}_{2} \mathrm{O}_{3}$ (53.5$56 \%), \mathrm{SiO}_{2}(6-7 \%), \mathrm{TiO}_{2}(5-6 \%), \mathrm{Na}_{2} \mathrm{O}(4-5 \%)$, and $\mathrm{CaO}(2-$ $3 \%)$. Mineralogically, red mud contains phases of undigested alumina, aluminosilicates, and phases of iron and titania. Alumina is in form of undigested gibbsite, alumogoethite, and sodalite along with silica and sodium (sodium aluminosilicates); iron is in form of hematite, alumogoethite, siderite, and ilmenite; titania is in form of anatase, rutile, and ilmenite; and calcium is in form of calcite. Average particle size of red mud is less than 10 microns with specific surface as $20.26 \mathrm{~m}^{2} / \mathrm{g}$.

The mineralogical composition of untreated red mud is

$$
\begin{aligned}
& \text { gibbsite: } \mathrm{Al}(\mathrm{OH})_{3} \text {, } \\
& \text { sodalite: } \mathrm{Na}_{2} \mathrm{O} \mathrm{Al}_{2} \mathrm{O}_{3} \cdot 2 \mathrm{SiO}_{2} \cdot 2 \mathrm{H}_{2} \mathrm{O} \text {, } \\
& \text { hematite: } \mathrm{Fe}_{2} \mathrm{O}_{3} \text {, } \\
& \text { alumogoethite: } \mathrm{FeAlOOH} \text {, } \\
& \text { anatase: } \mathrm{TiO}_{2} \text {, } \\
& \text { rutile: } \mathrm{TiO}_{2} \text {, } \\
& \text { ilmenite: } \mathrm{FeTiO}_{3} \text {, } \\
& \text { siderite: } \mathrm{FeCO}_{3} \text {, } \\
& \text { calcite: } \mathrm{CaCO}_{3} \text {. }
\end{aligned}
$$

Sodium present in red mud (total caustic soda) is in two forms: free or soluble caustic soda and bound caustic soda. Free caustic soda is the entrained liquor in the red mud slurry which gets incorporated during digestion process and remains with red mud in spite of repeated washings. Free soda is in the form of $\mathrm{NaOH}, \mathrm{Na}_{2} \mathrm{CO}_{3}, \mathrm{NaAlO}_{2}$, and so forth. The $\mathrm{pH}$ of the red mud is due to the presence of these alkaline solids in red mud. Bound soda is in the form of sodalite complex which can be stated as "NAS" phases: $3\left(\mathrm{Na}_{2} \mathrm{OAl}_{2} \mathrm{O}_{3} 2 \mathrm{SiO}_{2}\right) \mathrm{Na}_{2} \mathrm{X}\left(\mathrm{X}=\mathrm{CO}_{3}{ }^{2-}, 2 \mathrm{OH}^{-}, \mathrm{SO}_{4}{ }^{2-}, 2 \mathrm{Cl}^{-}\right)$ (Kurdowski and Sorrentino, 1997) [13]. In red mud, about 20$25 \%$ is the free or soluble caustic soda while the rest is in the form of sodalite complex.

Fly ash has the following composition: 57-58\% $\mathrm{SiO}_{2}$, 34-36\% $\mathrm{Al}_{2} \mathrm{O}_{3}$, and 4-6\% $\mathrm{Fe}_{2} \mathrm{O}_{3}$. Mineralogically fly ash contains about $75-80 \%$ quartz $\left(\mathrm{SiO}_{2}\right)$ with remaining mullite $\left(2 \mathrm{Al}_{2} \mathrm{O}_{3} \mathrm{SiO}_{2}\right)$, alumina in the form of mullite, and iron as hematite. 
2.2. Experimental Setup. Red mud, fly ash, and water were mixed in different proportions as per the experiments designed by Taguchi's methodology and kept in a crucible at different temperatures in a muffle furnace (CHEMINCO, Kolkata). After sintering the mixture for a fixed duration, the crucible was cooled overnight and the mixture was taken in a beaker and $100 \mathrm{~mL}$ distilled water was added. The mixture was stirred for 30 min using magnetic stirrer (Eltek M S 204). The $\mathrm{pH}$ of the slurry was measured after each test using LabX Light Titrator (Potentiometric Titrator), Mettler Toledo $\mathrm{GmbH}$, Switzerland.

\subsection{Taguchis Design of Experimental Methodology. Dr.} Taguchi of Nippon Telephones and Telegraph Company, Japan has developed a method based on "orthogonal array" experiments which gives much reduced "variance" for the experiment with "optimum settings" of control parameters. Taguchi methods [10] use orthogonal array distribution to design an experiment. A traditional experimental design to compare four independent variables at three different levels each requires a large number of individual experiments (eighty-one experiments). The logistical and resource implications of this experimental design make these experiments very difficult to carry out. By using $L_{9}$ orthogonal array with Taguchi method to design an experiment, a study involving 4 factors at 3 different levels can be conducted with only nine individual experiments. Taguchi method consists of 3 phases: designing the experiment, running and analyzing, and confirming and validating the experimental results. In an orthogonal array, each array can be identified by the form $L_{A}\left(B^{C}\right)$; the subscript of $L$, which is designated by $A$, represents the number of experiments that would be conducted using this design, and $B$ denotes the number of levels within each column which denotes how many levels could be investigated, while the letter $C$ indicates how many factors or variables could be included in the experiment [10].

$L_{9}$ orthogonal array consisting of four control parameters (factors), A, B, C, and D, is given in Table 1 and set at minimum, middle, and maximum value (i.e., levels 1,2 , and 3 ). The parameters were decided based on the preliminary experimentation carried out. In all nine experiments had to be conducted. Each experimental run was repeated thrice. The $\mathrm{pH}$ values (replicated thrice as $R_{1}, R_{2}$, and $R_{3}$ ) obtained for each experiment of the $L_{9}$ array are shown in Table 2. Subsequently analysis of variance (ANOVA) based on the Taguchi method was carried out using the values to determine the contribution of each parameter to the process of neutralization.

2.3.1. Treatment of Red Mud at High Temperature. The initial $\mathrm{pH}$ of the red mud slurry was 10.7 (50 gm of red mud was stirred with $100 \mathrm{~mL}$ of distilled water for $30 \mathrm{~min}$ ). After each experimental run, designed as per Taguchi's experimental methodology, $\mathrm{pH}$ of slurry was measured. The slurry sample with the lowest $\mathrm{pH}$ value and close to 7.0 (of experimental run number 7 ) was filtered using Whatman paper no. 40 . The filtered red mud was dried and analyzed.
TABLE 1: Experimental layout of parameters and their levels.

\begin{tabular}{lcccccc}
\hline \multirow{2}{*}{ Factors } & Parameters & \multirow{2}{*}{ Units } & \multicolumn{3}{c}{ Level } & \multirow{2}{*}{ Observed value } \\
& & & 1 & 2 & 3 & \\
\hline $\mathrm{A}$ & Weight of red mud & $\mathrm{g}$ & 10 & 20 & 30 & \\
$\mathrm{~B}$ & Weight of silicate & $\mathrm{g}$ & 10 & 20 & 30 & $\mathrm{pH}$ \\
& material & & & & & \\
$\mathrm{C}$ & Volume of water & $\mathrm{mL}$ & 8 & 10 & 12 & \\
$\mathrm{D}$ & Temperature & ${ }^{\circ} \mathrm{C}$ & 900 & 1000 & 1100 & \\
\hline
\end{tabular}

Chemical constituents of red mud mix obtained after sintering at the optimized condition were analyzed by using Wet Chemical Method. Untreated red mud, fly ash, and sintered red mud were analyzed mineralogically for determination of phases using XRD, X-ray diffractometer (PANalytical XPert Pro), using Cu K $\alpha$ radiation $(\lambda=1.54060 \AA)$. Scanning electron microscopy (SEM) has been conducted to study the morphology of neutralized red mud using Electron Probe Analyzer (MAKE: JEOL, Japan, JXA-840A).

The slurry sample was prepared from red mud sintered at the optimized condition of parameters (of experimental run number 7) and $100 \mathrm{~mL}$ distilled water and steered thoroughly. $\mathrm{pH}$ rebound phenomena were studied for 2-week time duration with this sample of red mud slurry.

2.3.2. Analysis of Experimental Data. The experimental data generated was analyzed by analysis of variance (ANOVA). Taguchi excel sheet is used for all the analysis which is based on Taguchi method for determination of main effects of the process parameters.

$R^{\prime}$ values are the ratio of neutral $\mathrm{pH}(7)$ to experimental $\mathrm{pH}$ value. $R_{1}^{\prime}, R_{2}^{\prime}$, and $R_{3}^{\prime}$ are the values calculated from $R_{1}, R_{2}$, and $R_{3}$. On this basis the "higher-is-better" quality characteristic was used in the analysis of experimental data. The plot of response curves and analysis of variance for raw data and $S / N$ ratio data was used for the analysis of results. The mean of the response characteristic $\mathrm{pH}\left(Y_{\mathrm{opt}}\right)$ at the optimal condition was estimated as

$$
\begin{aligned}
Y_{\mathrm{opt}}= & \frac{T}{N}+\left(\mathrm{A}_{1 \mathrm{avg}}-\frac{T}{N}\right)+\left(\mathrm{B}_{3 \mathrm{avg}}-\frac{T}{N}\right) \\
& +\left(\mathrm{C}_{3 \mathrm{avg}}-\frac{T}{N}\right)+\left(\mathrm{D}_{3 \mathrm{avg}}-\frac{T}{N}\right),
\end{aligned}
$$

where $T / N$ is the overall mean of the response, where $T$ is the grand total of all results and $N$ is the number of experiments, and $A_{1 \text { avg }}, B_{3 \text { avg }}, C_{3 \text { avg }}$, and $D_{3 \text { avg }}$ represent average values of response at the first level of parameter $\mathrm{A}$ and third levels of parameters $\mathrm{B}, \mathrm{C}$, and $\mathrm{D}$, respectively.

In order to confirm that the optimal parametric values using Taguchi's methodology are valid, selected confirmatory experiments were carried out under optimal conditions. The average of the results of the confirmation experiment is then compared with the anticipated average based on the optimal parameters and levels tested by Taguchi's methodology. The $Y_{\text {opt }}$ value obtained is 0.78 and $\mathrm{pH}$ value of which comes out to be 8.969 which is close to the optimized experimental 
TABLE 2: $L_{9}$ table and observed values of $\mathrm{pH}$.

\begin{tabular}{|c|c|c|c|c|c|c|c|c|c|c|c|}
\hline \multirow[b]{2}{*}{ Run } & \multicolumn{4}{|c|}{ Factors } & \multicolumn{3}{|c|}{ Final $\mathrm{pH}$} & \multicolumn{3}{|c|}{ Ratios of $\mathrm{pH}$} & \multirow[b]{2}{*}{$S / N$ ratio } \\
\hline & $\begin{array}{c}\text { A } \\
\text { Weight of red mud }\end{array}$ & $\begin{array}{c}\text { B } \\
\text { Weight of silicate material }\end{array}$ & $\begin{array}{c}\text { C } \\
\text { Volume of water }\end{array}$ & $\begin{array}{c}\text { D } \\
\text { Sintering temp. }\end{array}$ & $R_{1}$ & $R_{2}$ & $R_{3}$ & $R_{1}^{\prime}$ & $R_{2}^{\prime}$ & $R_{3}^{\prime}$ & \\
\hline 1 & 20 & 30 & 8 & 1000 & 9.12 & 9.25 & 9.3 & 0.77 & 0.76 & 0.75 & -2.40 \\
\hline 2 & 20 & 20 & 12 & 900 & 10.7 & 10.65 & 10.54 & 0.65 & 0.66 & 0.66 & -3.63 \\
\hline 3 & 30 & 10 & 12 & 1000 & 9.65 & 9.62 & 9.59 & 0.73 & 0.73 & 0.73 & -2.76 \\
\hline 4 & 10 & 20 & 10 & 1000 & 9.58 & 9.32 & 9.31 & 0.73 & 0.75 & 0.75 & -2.56 \\
\hline 5 & 30 & 20 & 8 & 1100 & 9.10 & 9.15 & 9.18 & 0.77 & 0.77 & 0.76 & -2.32 \\
\hline 6 & 30 & 30 & 10 & 900 & 10.68 & 10.55 & 10.61 & 0.66 & 0.66 & 0.66 & -3.62 \\
\hline 7 & 10 & 30 & 12 & 1100 & 8.9 & 8.92 & 8.88 & 0.79 & 0.78 & 0.79 & -2.09 \\
\hline 8 & 20 & 10 & 10 & 1100 & 9.27 & 9.25 & 9.3 & 0.76 & 0.76 & 0.75 & -2.43 \\
\hline 9 & 10 & 10 & 8 & 900 & 10.69 & 10.6 & 10.582 & 0.65 & 0.66 & 0.66 & -3.62 \\
\hline
\end{tabular}

TABLE 3: Average and main effects of ratios of $\mathrm{pH}$ values-Raw and $S / N$.

\begin{tabular}{lcccccccccc}
\hline \multirow{2}{*}{ Factors } & \multicolumn{3}{c}{ Raw data, average value } & \multicolumn{2}{c}{ Main effects } & \multicolumn{2}{c}{$S / N$ data, average value } & \multicolumn{2}{c}{ Main effects $(S / N$ data) } \\
& $L_{1}$ & $L_{2}$ & $L_{3}$ & $L_{2}-L_{1}$ & $L_{3}-L_{2}$ & $L_{1}$ & $L_{2}$ & $L_{3}$ & $L_{2}-L_{1}$ & $L_{3}-L_{2}$ \\
\hline A & 0.74 & 0.73 & 0.71 & -0.01 & -0.02 & -1.49 & -2.80 & -3.01 & -1.30 & -0.21 \\
B & 0.72 & 0.72 & 0.74 & 0.00 & 0.02 & -2.92 & -2.89 & -2.70 & 0.03 & 0.19 \\
C & 0.72 & 0.73 & 0.72 & 0.01 & 0.00 & -2.89 & -2.79 & -2.83 & 0.10 & -0.04 \\
D & 0.66 & 0.75 & 0.76 & 0.09 & 0.01 & -3.62 & -2.52 & -2.37 & 1.11 \\
\hline
\end{tabular}

value of 8.8-8.92 in run 7. The deviation between actual and determined $\mathrm{pH}$ by Taguchi's methodology is much within $5 \%$, and hence it is confirmed that the optimal parametric values determined by Taguchi's design are valid.

2.4. Utilization of Red Mud. Red mud was used as an alternative to clay in making bricks. Four standard size bricks were made by mixing suitable proportions of red mud, fly ash, and water. The bricks were made in commercial fly ash brick factory machine, that is, Brickman machine. They were pressed at $\sim 200 \mathrm{~kg} / \mathrm{cm}^{2}$, dried overnight in an oven at $110^{\circ} \mathrm{C}$, and sintered at $1100^{\circ} \mathrm{C}$ for 2 hours. The composition of the raw materials used and the properties of the bricks obtained are given in Table 6 . The brick samples were tested for cold compressive strength (CCS), water absorption (WA), efflorescence and bulk density.

\section{Results and Discussion}

3.1. Effect of the Process Parameters on $p H$. Table 3 provides the raw data for the average value ratios of $\mathrm{pH}$ and $S / N$ ratio for each parameter at levels 1,2 , and 3 . The sintering temperature from level 1 to level 2 has the greatest influence on value of $\mathrm{pH}$. The difference between the levels also shows the same trend. Figure 1 shows the response curves of the individual parameters on the ratio of $\mathrm{pH}$ values, that is, $R^{\prime}$ values (7/experimental $\mathrm{pH}$ value) and $S / N$ ratio.

From Figure 1, it can be seen that the ratio of $\mathrm{pH}$ decreases with the increase in the weight of red mud (factor A). It is due to the increase in free caustic soda in the slurry with the increase in quantity of red mud. There is a sharp decrease in the ratio of $\mathrm{pH}$ values when factor $\mathrm{A}$ changes

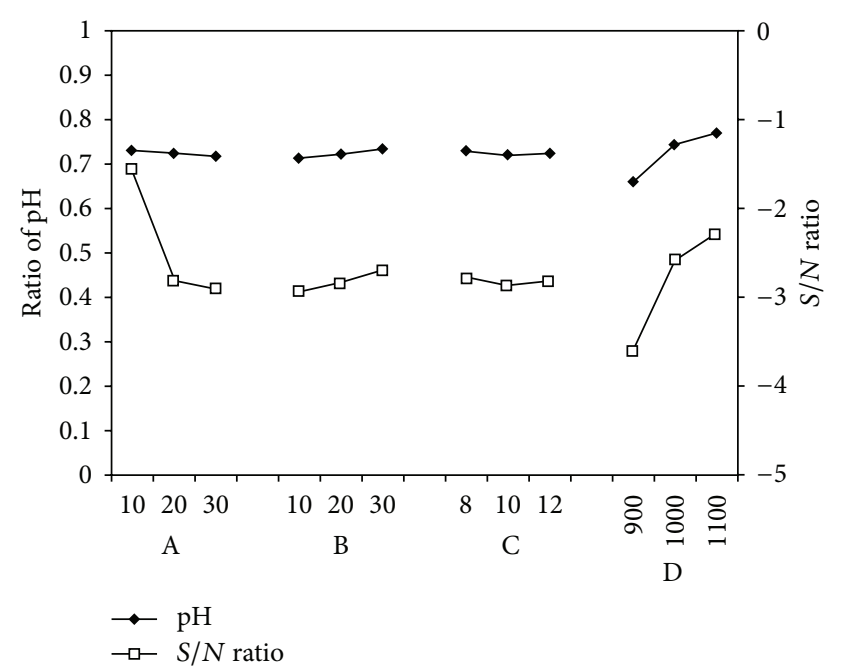

FIGURE 1: Main effects of each factor on ratio of $\mathrm{pH}$ along with $S / N$ ratio of treated red mud slurry (ANOVA analysis). A: wt. of red mud (g); B: wt. of silicate material (g); C: vol of water (mL); D: temp. $\left({ }^{\circ} \mathrm{C}\right)$.

from level 1 to 2 and also when the quantity of red mud changes from level 2 to 3 . Sintering temperature (factor D) definitely decreases the $\mathrm{pH}$ of the slurry as a sharp increase in the ratio of $\mathrm{pH}$ is observed from level 1 to 2 . Further increase in the ratio of $\mathrm{pH}$ values (i.e., decrease in $\mathrm{pH}$ ) is observed from level 2 to level 3. Not much change in $\mathrm{pH}$ is observed at $900^{\circ} \mathrm{C}$ but the change is seen above this temperature. The increase in temperature decreases the $\mathrm{pH}$ substantially due to the fusion of free soda with the silica and alumina present in fly ash. The overall results convey that the $\mathrm{pH}$ 
TABle 4: ANOVA table.

\begin{tabular}{lcccccc}
\hline Factors & Total variance of each factor & Degree of freedom & Variance & Variance ratio & Pure sum of sq. & Percent contribution \\
\hline A & 0.001 & 2 & 0.000 & 10.5651 & 0.00062816 & 1.090 \\
B & 0.002 & 2 & 0.001 & 29.82904 & 0.00189326 & 3.079 \\
C & 0.000 & 2 & 0.000 & 4.087215 & 0.00020274 & 0.422 \\
D & 0.060 & 2 & 0.030 & 915.4204 & 0.06005186 & 94.480 \\
Error & 0.001 & 18 & 0.000 & 1 & 0.00032836 & 0.929 \\
\hline Totals & 0.064 & 26 & 0.032 & & & 100.000 \\
\hline
\end{tabular}

TABLE 5: Mineralogical phases in sintered red mud.

\begin{tabular}{lcc}
\hline Compound name & Chemical formula & JCPDS no. \\
\hline Corundum & $\mathrm{Al}_{2} \mathrm{O}_{3}$ & $00-046-1212$ \\
Sillimanite & $\mathrm{Al}_{2} \mathrm{SiO}_{5}$ & $00-038-0471$ \\
Jadeite & $\mathrm{NaAlSi}_{2} \mathrm{O}_{6}$ & $00-022-1338$ \\
Burnt ochre & $\mathrm{Fe}_{2} \mathrm{O}_{3}$ & $00-033-0664$ \\
Aluminum iron oxide & $\mathrm{AlFeO}_{3}$ & $00-030-0024$ \\
Brookite & $\mathrm{TiO}_{2}$ & $00-015-0875$ \\
Calcium oxide & $\mathrm{CaO}_{2}$ & $00-037-1497$ \\
Calcium silicate & $\mathrm{Ca}_{2} \mathrm{SiO}_{4}$ & $00-031-0299$ \\
Grossular & $\mathrm{Ca}_{3} \mathrm{Al}_{2}\left(\mathrm{SiO}_{4}\right)_{3}$ & $00-039-0368$ \\
Sodium aluminum oxide & $\mathrm{NaAlO}_{2}$ & $00-033-1200$ \\
\hline
\end{tabular}

of the slurry is mostly affected by the sintering temperature. The lowest $\mathrm{pH}$ is obtained with the weight of red mud at level 1 , weight of silicate material at level 3 , water at level 3 , and temperature at level $3\left(\mathrm{~A}_{1} \mathrm{~B}_{3} \mathrm{C}_{3} \mathrm{D}_{3}\right)$. The contribution of individual parameters was weighted as shown in Table 4 with analysis of variance (ANOVA) to see their effect on desired response characteristic $(\mathrm{pH})$. The most significant parameters are found to be the sintering temperature with a very high contribution of $94.48 \%$ followed by weight of red mud $(1.09 \%)$ and weight of silicate material (3.08\%) and water $(0.5 \%)$.

3.2. Confirmation Experiment. From Table 2, it can be seen that the experimental condition $\left(\mathrm{A}_{1} \mathrm{~B}_{3} \mathrm{C}_{3} \mathrm{D}_{3}\right)$ was the one in which the lowest value of $\mathrm{pH}$ value was achieved (8.888.9) which was close to the neutral value of 7 in all the 3 replications. As per the Guidelines of Australian and New Zealand Environment and Conservation Council (ANZEX) and Agriculture and Resource Management Council of Australia and New Zealand (ARMCANZ), the liquor being strongly alkaline with a high $\mathrm{pH}$ requires neutralization to a pH below 9 with an optimum value of 8.5-8.9 before becoming environmentally benign [14]. The optimized condition obtained from Figure 1 was $\mathrm{A}_{1} \mathrm{~B}_{3} \mathrm{C}_{3} \mathrm{D}_{3}$ having $\mathrm{pH}$ value of about 8.90 which is the lowest of all the values. Hence these conditions were fine-tuned by increasing the temperature to $1200^{\circ} \mathrm{C}$ and the $\mathrm{pH}$ achieved was 8.34 which is within the acceptable limit. Hence the final optimized conditions to achieve a $\mathrm{pH}$ of 8.9 were $25-50 \%$ of red mud and $50-$ $75 \%$ silicate material, with water $(10 \%)$ and a temperature of $1100^{\circ} \mathrm{C}$. Alternatively $50 \%$ of red mud can be mixed with $50 \%$ of fly ash with water at temperature of $1200^{\circ} \mathrm{C}$ to get a $\mathrm{pH}$ of about 8.4. The results are in accordance with those obtained by investigators [4]. In absence of sintering, studies carried out at Jamaica [15] show that in neutralization of red mud with acidic fly ash, a large amount of fly ash is required with very slow neutralization rate (approx. 150 days to get a $\mathrm{pH}$ from 12.5 to 11$)$.

\subsection{Red Mud Analysis after Neutralization}

3.3.1. Chemical Analysis. The chemical analysis of red mud after sintering is $\mathrm{Al}_{2} \mathrm{O}_{3}: 24.50 \%, \mathrm{Fe}_{2} \mathrm{O}_{3}: 31.92 \%, \mathrm{SiO}_{2}: 34.50 \%$, $\mathrm{TiO}_{2}: 2.53 \%, \mathrm{Na}_{2} \mathrm{O}: 4.5 \%$, and $\mathrm{CaO}: 1.09 \%$. Sintered red mud has high alumina content, low iron content, and high silica content due to the addition of silicate material (fly ash) and subsequent sintering of the mixture as compared to the original red mud.

3.3.2. Formation of Different Phases. To investigate the phase structures of the red mud, the X-ray diffraction pattern was measured. Figure 2 shows the XRD pattern which shows a well crystallized sintered red mud powder. The peaks of the red mud show the phases as shown in Table 5. Alumina present in red mud in the hydroxide form has been converted into corundum which is alpha phase of alumina. Alumina has also reacted with silica from fly ash to form aluminosilicates (sillimanite) which impart strength to the fused material. Caustic soda has fused with alumina and silica to form sodium silicates and sodium aluminosilicates. Some of the free soda is still present in the sintered red mud in form of sodium aluminate. Hence $\mathrm{pH}$ value of above 8.9 is observed after the process. Calcium aluminosilicates and calcium silicates are also formed.

Some of the reactions taking place in the process are

$$
\begin{gathered}
\mathrm{Na}_{2} \mathrm{CO}_{3}+\mathrm{SiO}_{2} \longrightarrow \mathrm{Na}_{2} \mathrm{SiO}_{3}+\mathrm{CO}_{2} \\
2 \mathrm{NaOH}+\mathrm{SiO}_{2} \longrightarrow \mathrm{Na}_{2} \mathrm{SiO}_{3}+\mathrm{H}_{2} \mathrm{O} \\
\mathrm{Na}_{2} \mathrm{SiO}_{3}+\mathrm{Al}_{2} \mathrm{O}_{3} \longrightarrow \mathrm{Al}_{2} \mathrm{O}_{3} \cdot \mathrm{SiO}_{2} \cdot \mathrm{Na}_{2} \mathrm{O} \\
3 \mathrm{Al}_{2} \mathrm{O}_{3}+2 \mathrm{SiO}_{2} \longrightarrow 3 \mathrm{Al}_{2} \mathrm{O}_{3} \cdot 2 \mathrm{SiO}_{2}
\end{gathered}
$$

3.3.3. Morphology of Red Mud. Figure 3 shows the morphological structure of original (untreated) red mud as seen in SEM which indicates scattered fine particles of about 1 micron size. Globular particles with smooth surface which are formed due to the formation of sodium aluminosilicates are observed (Figure 4) in sintered red mud. 


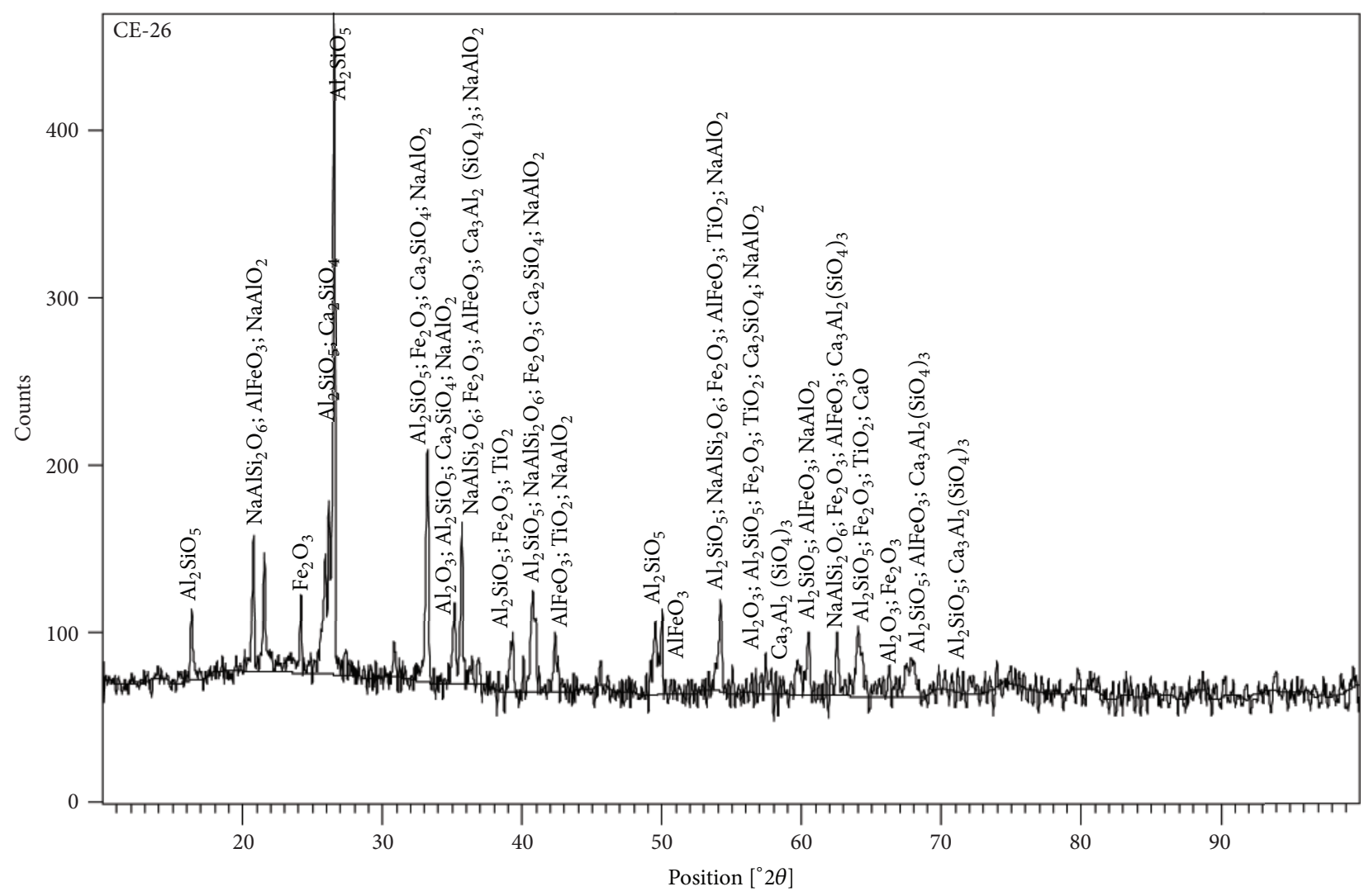

Figure 2: Mineralogical phases of sintered red mud mix with fly ash (XRD). Conditions: red mud: fly ash $(1: 3)$ with $10 \%$ water, $1100^{\circ} \mathrm{C}$.

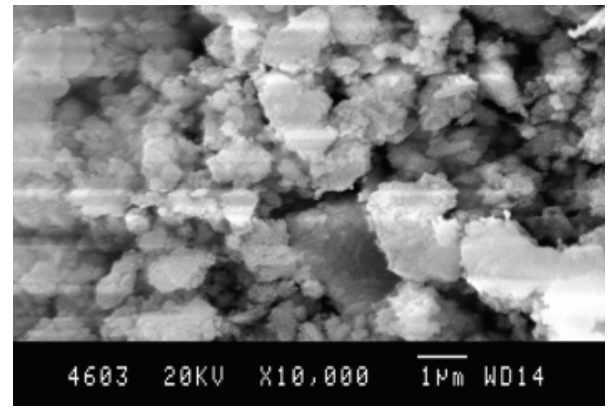

FIGURE 3: SEM photograph of untreated red mud.

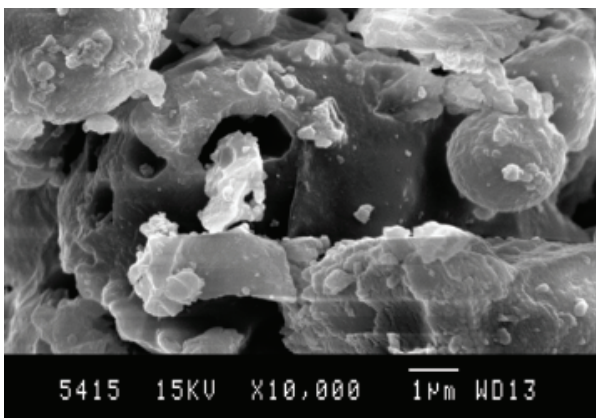

FIGURE 4: SEM photograph of sintered red mud.
3.3.4. Physical Characteristics of Red Mud. Physical characteristics of sintered red mud improve to a large extent as fast filtration of sintered red mud slurry is observed. Also the color of filtrate is clear as compared to filtrate obtained with untreated red mud.

3.4. Utilization of Sintered Red Mud. The chemical, mineralogical, and morphological properties of sintered red mud show that the material can be used in construction industry in place of clay. It can be utilized as a replacement of naturally available building material and for the production of new building materials. The developed bricks are having very good strength with CCS\% ranging from 30 to $135 \mathrm{~kg} / \mathrm{cm}^{2}$ with slightly more value of WA\% as shown in Table 6.
The bricks are included in the class of 3.5 to 12.5 . These promising results show that technically these bricks are suitable for construction of load-bearing walls. Red mud blocks can also be made from these mixtures which can also be used as a low cost housing material. Red mud in the range of $40-60 \%$ can be used for making good quality bricks. Efforts have been made at Central building Research Institute (CBRI), India, to produce burnt clay bricks by partially replacing the clay with red mud, lime, and fly-ash [16].

3.5. $p H$ Rebound. The increase in $\mathrm{pH}$ and aluminium concentration after the neutralization of red mud is commonly known as reversion or rebound. No $\mathrm{pH}$ rebound was observed with the optimized sample as the $\mathrm{pH}$ remained 
TABLE 6: Composition and properties of bricks.

\begin{tabular}{lccccccc}
\hline & \multicolumn{2}{c}{ Brick composition } & & \multicolumn{4}{c}{ Properties of bricks } \\
& Red mud (\%) & Fly ash (\%) & CCS $\left(\mathrm{kg} / \mathrm{cm}^{2}\right)$ & WA (\%) & Efflorescence & Bulk density (g/cc) & Class of brick \\
\hline Composition 1 & 50 & 50 & 31.7 & 24.0 & Nil & 1.47 & Class 3.5 \\
Composition 2 & 45 & 55 & 66.93 & 24.50 & Nil & 1.49 & Class 5 \\
Composition 3 & 40 & 60 & 86.73 & 23.8 & Nil & 1.50 & Class 7.5 \\
Composition 4 & 35 & 65 & 134.18 & 24.10 & Nil & 1.51 & Class 12.5 \\
\hline
\end{tabular}

the same even after two weeks. This means that there is no more caustic soda leaching after its initial leaching from sintered red mud.

\section{Conclusion}

The paper has discussed in detail the feasibility of sintering of red mud to deal with the caustic soda in it using Taguchi's methodology. The $\mathrm{pH}$ of red mud slurry reaches values within the acceptable limits after sintering red mud with a silicate material (fly ash) at a very high temperature of $1100-1200^{\circ} \mathrm{C}$. The method of treating red mud with fly ash along with water can be a successful process to tackle the caustic soda problem. Also the resultant material can be reused as a construction material in place of clay. Taguchi's experimental methodology is found to be a valuable tool. The ANOVA analysis using Taguchi methodology shows that the most significant parameters are temperature of calcinations $(94.48 \%)$ followed by weight of red mud (1.09\%) and quantity of fly ash (3.079\%). The optimized conditions to achieve a $\mathrm{pH}$ value of about 8.9 were $25-50 \%$ of red mud mixed with $50-75 \%$ of fly ash with water $(10 \%)$ and a temperature of $1100^{\circ} \mathrm{C}$. Alternatively about $50 \%$ of red mud with $50 \%$ of fly ash and $1200^{\circ} \mathrm{C}$ can be used where the $\mathrm{pH}$ obtained is within the permissible limit of 8.4.

The study shows that treatment of red mud with fly ash at a very high temperature lowers down the $\mathrm{pH}$ and hence alkalinity of red mud slurry permanently without $\mathrm{pH}$ rebound. This also modifies the physical characteristics as is evident from the morphology of red mud. Sintering of residue can be carried out to fix all leachable soda and to achieve high strength during the sintering process. Thus red mud can be used as an alternative to clay material in building and construction industry. Both red mud and fly ash can be reused. However, the cost would be very high due to the high energy consumption as an elevated temperature is required for sintering. But the process would certainly help in reducing pollution of soil, air, and water and would considerably save resources of mother earth.

\section{References}

[1] R. K. Paramguru, P. C. Rath, and V. N. Misra, "Trends in red mud utilization-a review," Mineral Processing \& Extractive Metallurgy Review, vol. 26, no. 1, pp. 1-29, 2005.

[2] U. V. Parlikar, P. K. Saka, and S. A. Khadilkar, "Technological options for effective utilization of bauxite residue (Red mud) a review," in International Seminar on Bauxite Residue (RED MUD), Goa, India, October 2011.
[3] S. B. Rai, K. L. Wasewar, J. Mukhopadhaya, K. Chang, and H. Uslu, "Neutralization and Utilization of red mud for its better waste management," Archives of Environmental Science, vol. 6, pp. 13-33, 2012.

[4] F. Puskas, "Process for the utilization in the ceramics industry of red mud from alumina plants," US Patent 4368273, 1983.

[5] B. Garhard, "Method for producing bricks from red mud," US Patent 3886244, 1975.

[6] K. G. K. Warrier, P. Krishna Pillai, P. Perumal, and C. L. Verma, "Liquid phase sintering of flyash to produce high volume flyash ceramics for a variety of applications," CSIR News, vol. 54, pp. 13-14, 2004.

[7] Wealth from waste, special Report, "Construction World (Indian Edition)," 2002, http://www.constructionupdate.com/ products/constructionworld/2002/jan2002/010.html.

[8] D. M. Byrne and S. Taguchi, "The Taguchi approach to parameter Design ," Quality Progress, vol. 20, no. 12, pp. 19-26, 1987.

[9] P. J. Ross, Taguchi Techniques for Quality Engineering, McGraw Hill, New York, NY, USA, 1996.

[10] G. S. Peace, Taguchi Methods: A Hands-on Approach, AddisonWesley, 1993.

[11] S. B. Rai, K. L. Wasewar, D. H. Lataye et al., "Neutralization of red mud with pickling waste liquor using Taguchi's design of experimental methodology," Waste Management and Research, vol. 30, no. 9, pp. 922-930, 2012.

[12] S. B. Rai, K. L. Wasewar, D. H. Lataye, and J. Mukhopadhyay, "Feasibility of red mud neutralization with Seawater using Taguchi's methodology," International Journal of Environmental Science and Technology, vol. 10, no. 2, pp. 305-314, 2013.

[13] W. Kurdowski and F. Sorrentino, Waste Materials Used in Concrete Manufacturing, Edited by S. Chandra, William Andrew, Noyes, 1997.

[14] C. Hanahan, D. McConchie, J. Pohl, R. Creelman, M. Clark, and C. Stocksiek, "Chemistry of seawater neutralization of bauxite refinery residues (red mud)," Environmental Engineering Science, vol. 21, no. 2, pp. 125-138, 2004.

[15] S. Khaitan, D. A. Dzombak, and G. V. Lowry, "Chemistry of the acid neutralization capacity of bauxite residue," Environmental Engineering Science, vol. 26, no. 5, pp. 873-881, 2009.

[16] A. Dass and S. K. Malhotra, "Lime-stabilized red mud bricks," Materials and Structures, vol. 23, no. 4, pp. 252-255, 1990. 

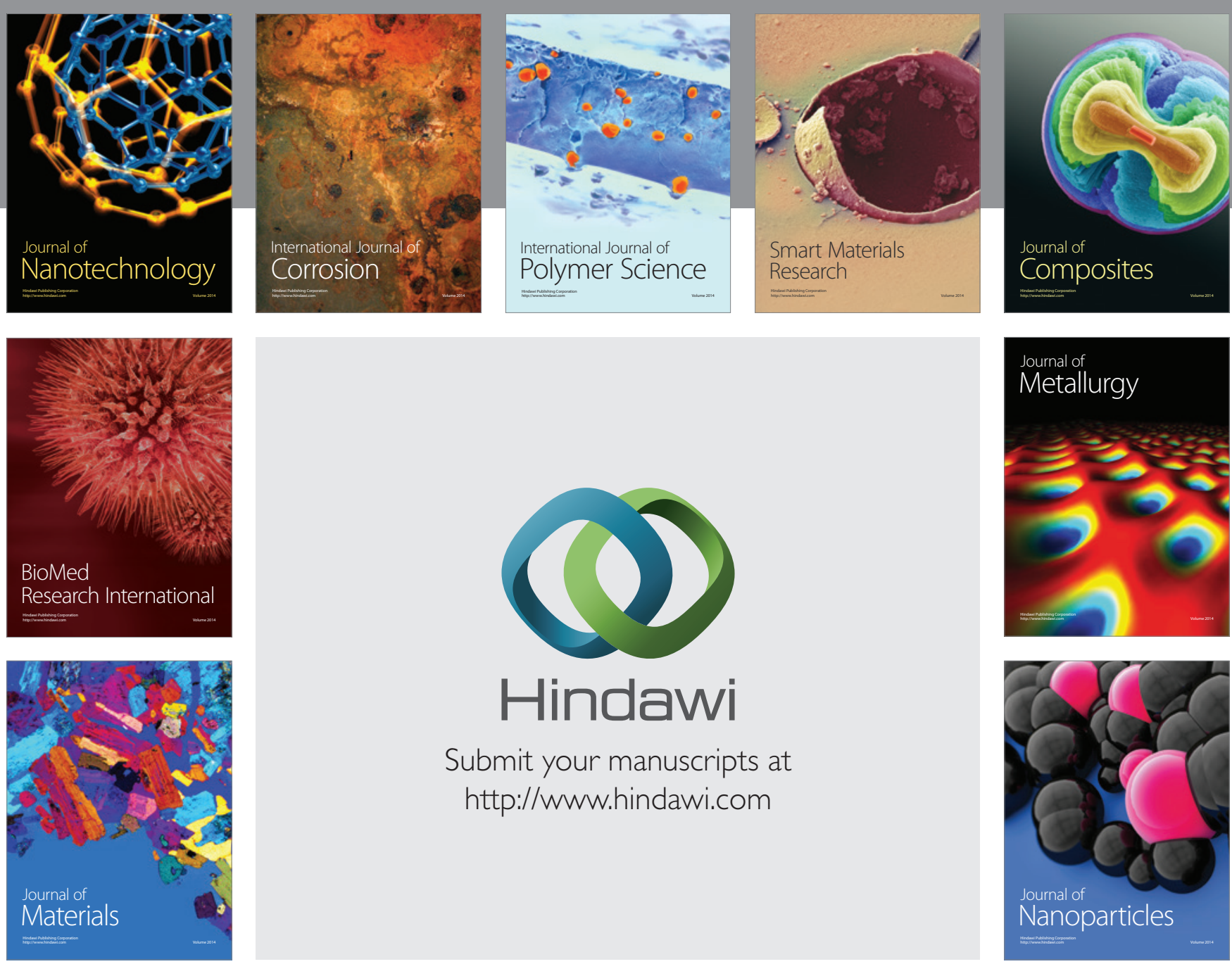

Submit your manuscripts at http://www.hindawi.com
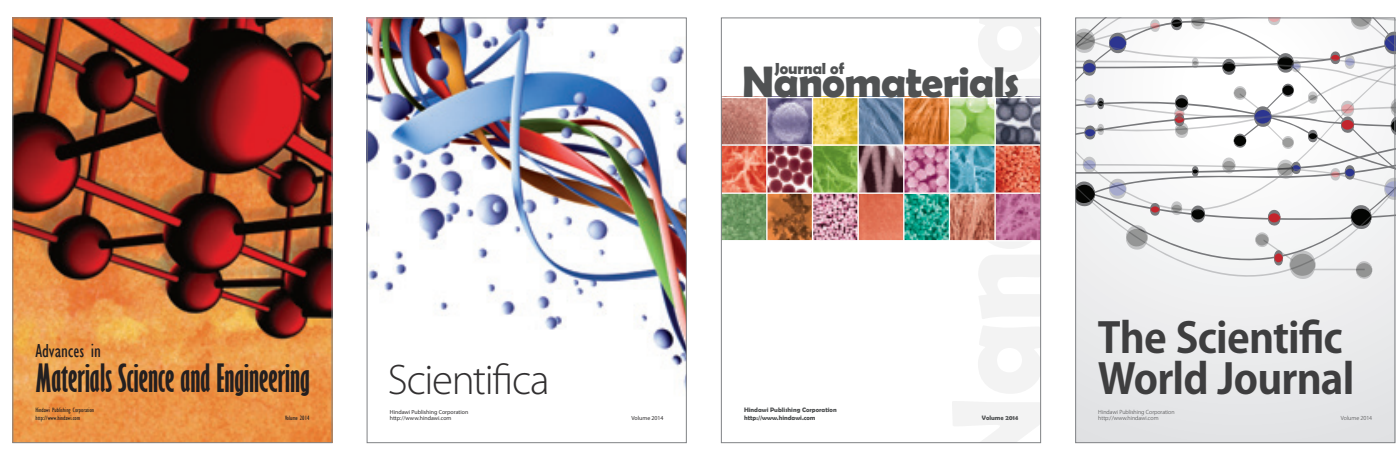

\section{The Scientific World Journal}
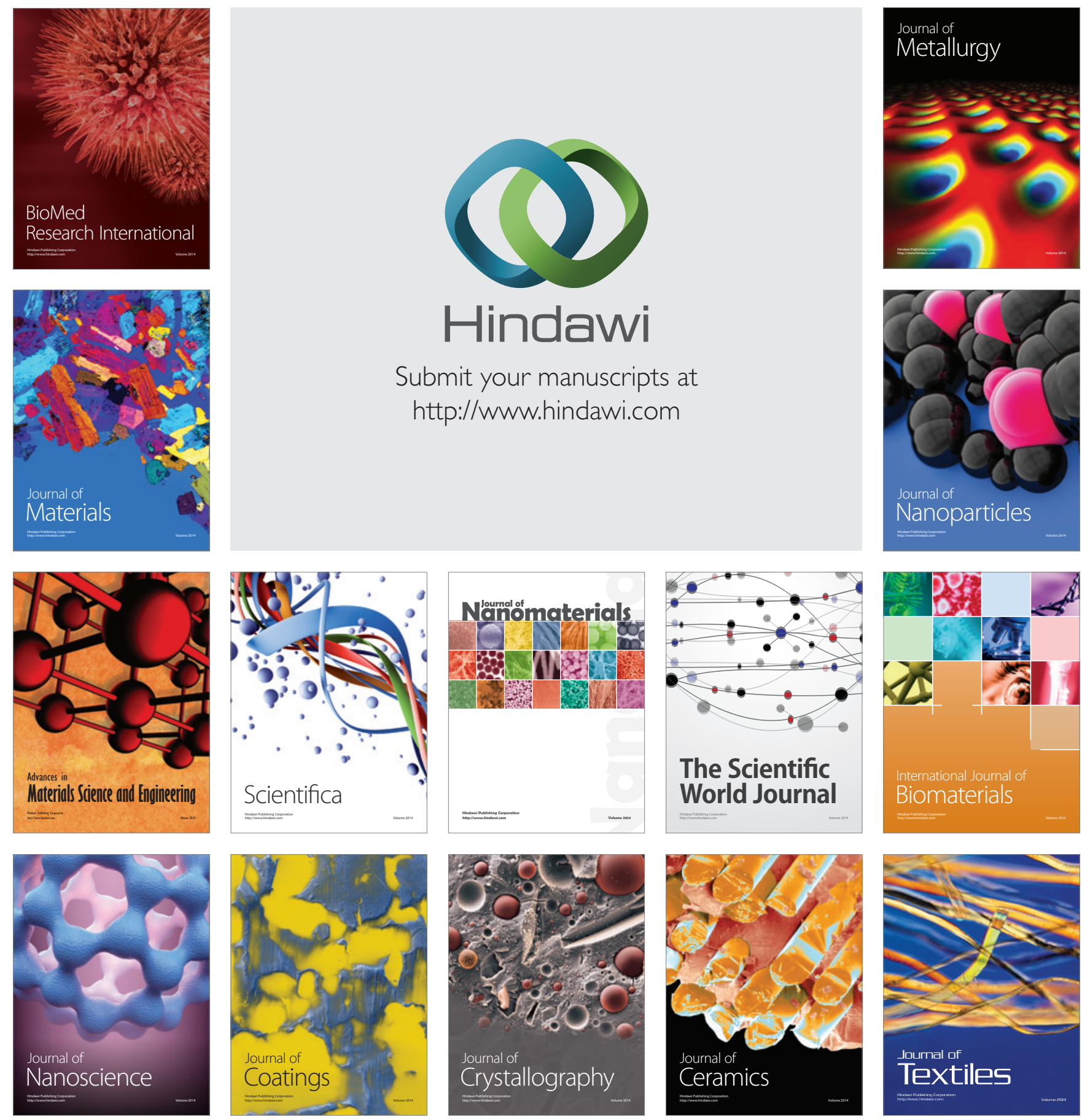